\title{
STUDI PENGATURAN KECEPATAN MOTOR INDUKSI TIGA PHASA MENGGUNAKAN VARIABLE SPEED DRIVE (VSD) BERBASIS PROGRAMMABLE LOGIC CONTROLLER (PLC)
}

\author{
${ }^{1,2,3}$ Riski Anda Rangkuti, Atmam, Elvira Zondra \\ ${ }^{1,2,3}$ Program Studi Teknik Elektro, Fakultas Teknik, Universitas Lancang Kuning Pekanbaru. \\ Jl. Yos Sudarso km. 8 Rumbai, Pekanbaru, Telp. (0761) 52324 \\ E-mail: riskiandarangkuti@gmail.com, atmam@unilak.ac.id, elviraz@unilak.ac.id
}

\begin{abstract}
Abstrak
Motor induksi merupakan motor listrik arus bolak balik (AC) yang paling banyak digunakan saat ini, karena memiliki konstruksi yang sederhana, relatif murah serta mudah dalam pemeliharaannya. Motor induksi juga banyak digunakan untuk berbagai keperluan dalam proses produksi pada suatu industri. Dengan berkembangnya teknologi sistem kontrol salah satu cara yang dilakukan adalah dengan menggunakan kendali Variable Speed Drive (VSD) yang dihubungkan langsung dengan motor induksi 3 phasa untuk mengatur kecepatan, dan ditambah dengan menggunakan Programmable Logic Controller (PLC) yang berfungsi sebagai pengendali Variable Speed Drive (VSD) untuk mengatur kecepatan motor induksi 3 phasa. Kecepatan motor induksi tiga phasa saat tidak terkopel beban sebesar 2802 rpm dengan frekuensi $50 \mathrm{~Hz}$, kecepatan $1681 \mathrm{rpm}$ pada frekuensi $30 \mathrm{~Hz}$ dan kecepatan 840,6 rpm pada frekuensi $15 \mathrm{~Hz}$. Dengan kondisi terkopel beban kecepatan motor induksi tiga phasa sebesar $1434 \mathrm{rpm}$ dengan frekuensi 25,6 $\mathrm{Hz}$, kecepatan $1462 \mathrm{rpm}$ pada frekuensi $26,1 \mathrm{~Hz}$ dan kecepatan $1496 \mathrm{rpm}$ pada frekuensi 26,6 Hz. Frekuensi berbanding lurus terhadap kecepatan motor induksi 3 phasa, semakin besar frekuensi yang masuk pada motor induksi 3 phasa maka akan semakin cepat putaran motor induksi 3 phasa tersebut.
\end{abstract}

Kata kunci : Motor Induksi 3 Phasa, Variable Speed Drive (VSD), Programmable Logic Controller (PLC).

\begin{abstract}
Induction motor is an alternating electric motor (AC) which is most widely used today because it has a simple construction, is relatively inexpensive and is easy to maintain. Induction motors are also widely used for various purposes in the production process in an isdustry. With the development of control system technology, one way to do this is by using Variable Speed Drive (VSD) that are connected directly to a 3phase indction motor to regulate speed and, in additional, by using a Programmable Logic Control (PLC) that functions as a Variable Speed Drive (VSD) to set the speed of the 3-phase induction motor. The results of the test of the speed of the uncoupled 3-phase induction motor are: a speed of $280 \mathrm{rpm}$ with a frequency of $50 \mathrm{~Hz}$, speed of $1681 \mathrm{rpm}$ with a frequency of $30 \mathrm{~Hz}$, and speed of 840,6 rpm at a freqency of $15 \mathrm{~Hz}$. With coupled conditions, the speed of the 3-phase induction motor are: a speed of 1434 rpm with a frequency of $25,6 \mathrm{~Hz}$, a speed of $1462 \mathrm{rpm}$ at a frequency of $26,1 \mathrm{~Hz}$ and a speed of $1496 \mathrm{rpm}$ at a frequency of 26,6 $\mathrm{Hz}$. The frequency is directly proportional to the speed of the 3-phase induction motor; and the greater the frequency entered in the 3-pahse inuction motor, the faster the rotation of the 3-phase induction motor.
\end{abstract}

Keywords: 3-phase induction motor, Variable Speed Drive (VSD), Programmable Logic Control (PLC).

\section{PENDAHULUAN}

Motor induksi merupakan salah satu motor listrik paling umum yang banyak digunakan dalam kehidupan sehari-hari. Motor induksi juga banyak digunakan untuk berbagai keperluan dalam proses produksi pada suatu industri. Kehandalan dan kemudahan penggunaan motor induksi merupakan alasan bagi dunia industri untuk menggunakannya.
Bila dilihat dari sisi sumber tegangan motor induksi, salah satunya dengan motor induksi tiga phasa.

Motor induksi tiga phasa mempunyai kelemahan sulitnya mengendalikan kecepatan, karena motor induksi tiga phasa berputar pada kecepatan konstan, sedangkan pada sebuah industri biasanya menginginkan motor listrik yang bisa diatur kecepatannya sesuai dengan keinginan. Bila beban berubah kecepatan motor induksi tiga phasa 
juga akan berubah, untuk mempertahankan agar kecepatan pada motor induksi tiga phasa tetap konstan maka tegangan dan frekuensi harus diatur.

Untuk mengatur kecepatan motor induksi tiga phasa yaitu salah satunya dengan cara mengubah frekuensi, Untuk mengatur frekuensi yang masuk pada motor induksi tiga phasa tersebut dapat menggunakan kendali Variable Speed Drive (VSD) yang dihubungkan langsung dengan motor induksi tiga phasa.

Variable Speed Drive atau Variable Frekuensi Drive adalah suatu alat yang digunakan untuk mengendalikan kecepatan motor listrik (AC) dengan mengontrol frekuensi daya listrik yang dipasok ke motor. Variable Frekuensi Drive semakin popular karena kemampuannya untuk mengontrol kecepatan motor induksi [1].

Programmable Logic Controller (PLC). Programmable Logic Controller (PLC) ini yang nantinya digunakan sebagai pengendali kecepatan pada motor induksi tiga phasa dengan menghubungkannya dengan Variable Speed Drive (VSD). Programmable Logic Controller (PLC) merupakan alat yang berfungsi untuk mengontrol rangkaian secara otomatis.

Programmable Logic Controller (PLC) adalah sebuah alat yang digunakan untuk menggantikan rangkaian sederetan relay yang dijumpai pada sistem kontrol proses konvensional. Programmable Logic Controller (PLC) bekerja dengan mengamati masukan (melalui sensor-sensor terkait), kemudian melakukan proses dan melakukan tindakan sesuai yang dibutuhkan, yang berupa menghidupkan atau mematikan luarannya (logic 0 atau 1, hidup atau mati) [2].

\section{METODE PENELITIAN}

Untuk perancangan sistem pengendalian kecepatan motor induksi tiga phasa dengan menggunakan Variable Speed Drive (VSD) berbasis Programmable Logic Controller (PLC) dibagi atas dua bagian yaitu perancangan perangkat keras sistem (hardware) dan perancangan perangkat lunak (software).

Perancangan perangkat keras (hardware) terdiri atas beberapa perancangan setiap blok yang menyusun sistem kontrol secara keseluruhan. Perancangan perangkat lunak (software) yaitu pembuatan diagram ladder sebagai program untuk mengontrol Variable Speed Drive (VSD) sebagai alat untuk merubah frekuensi yang yang selanjutnya untuk mengatur kecepatan motor induksi tiga phasa.

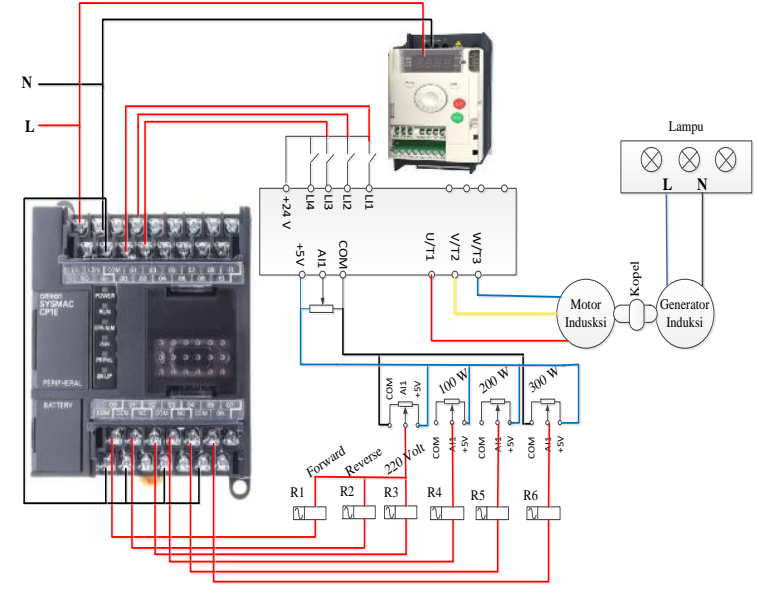

Gambar 1. Perancangan PLC Dengan VSD

\section{Perancangan Perangkat Keras (Hardware)}

Spesifikasi motor induksi tiga phasa yang digunakan terdapat pada Tabel 1.

Tabel 1. Spesifikasi motor induksi

\begin{tabular}{cc}
\hline Parameter & Keterangan \\
\hline Tegangan & $220 / 380$ Volt \\
Hubungan & $\Delta / \mathrm{Y}$ \\
Arus & $3,11 / 1,80 \mathrm{~A}$ \\
Daya & $1 \mathrm{HP}$ \\
rpm & $0,75 \mathrm{~kW}$ \\
Frekuensi & $2800 \mathrm{rpm}$ \\
Jumlah Kutub & $50 \mathrm{~Hz}$ \\
\hline
\end{tabular}

\section{Perancangan VSD ATV12H075M2}

Pengaturan ATV12H075M2 disesuaikan dengan spesifikasi motor yang digunakan / name plate pada motor. Perancangan VSD menggunakan sistem digital input yaitu Setting drive parameter. Pada pengaturan ini dimasukkan parameterparameter sesuai dengan rating motor dan kebutuhan kecepatan motor.

\section{Pengkabelan ATV12H075M2}

Pengkabelan atau Wiring pada Variable Speed Drive (VSD) sangatlah penting, karena pada tiap terminal altivar yang dihubungkan ke driver maupun beban berupa motor induksi tiga phasa mempunyai fungsi dan peranannya masing-masing. Pengkabelan seperti pada Gambar 2 dan Gambar 3. 


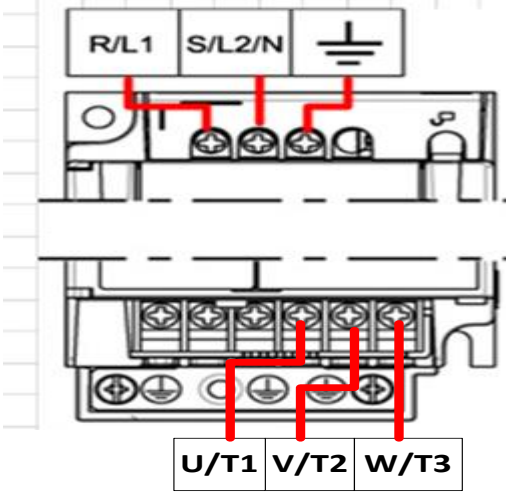

Gambar 2. Wiring Power Terminal VSD

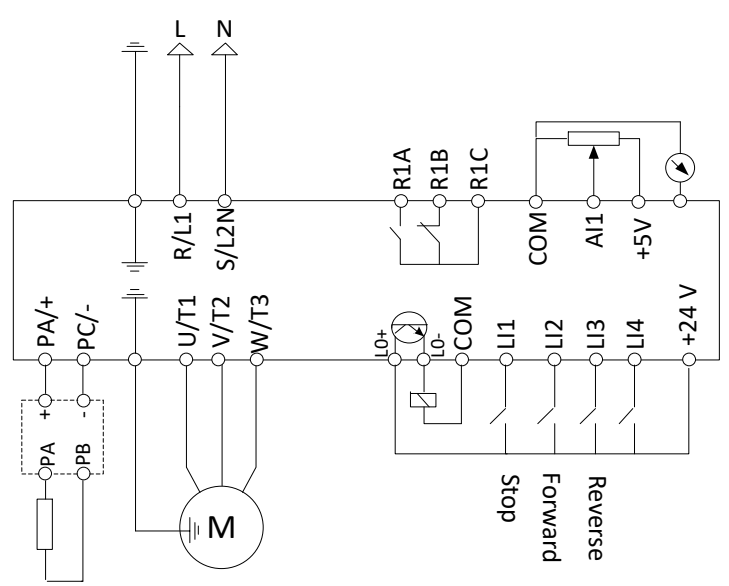

Gambar 3. Wiring diagram VSD

\section{Rangkaian Input dan Output PLC}

Dalam sistem pengendalian untuk kecepatan motor induksi tiga phasa menggunakan $V S D$ berbasis $P L C, \quad P L C$ bekerja sebagai kontrol perpindahan frekuensi yang ada di VSD, PLC merupakan perpaduan antara perangkat keras dan perangkat lunak (Hardware dan software). PLC akan bekerja sesuai dengan ladder diagram yang telah kita buat. Untuk pemograman dan pengiriman data menggunakan aplikasi CX-Programmer. Berikut rangkaian pengawatan input dan output digital PLC pada Gambar 4 dan Gambar 5.

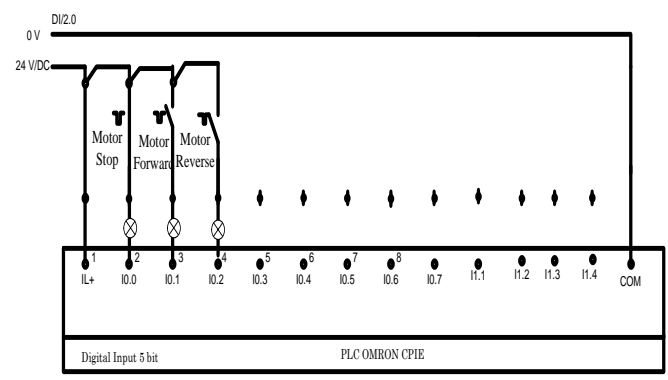

Gambar 4. Wiring Input Digital

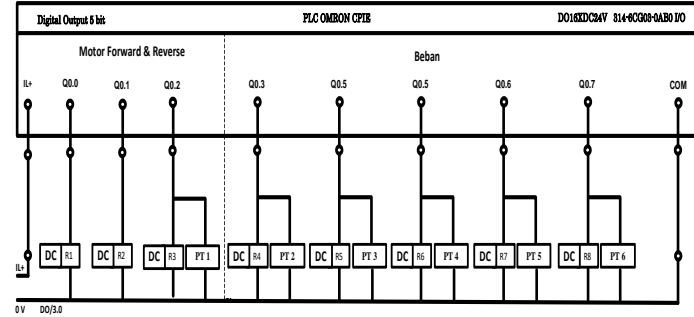

Gambar 5. Wiring Output Digital

\section{Perancangan Perangkat Lunak (Software)}

Dalam sistem pengaturan kecepatan motor induksi tiga phasa menggunakan PLC sebagai alat kontrol keceptan motor induksi melalui VSD. Perancangan perangkat lunak berupa pemrograman yang membuat sistem dapat bekerja sesuai dengan cara kerja alat.

\section{Pengalamatan Input dan Output PLC Omron CP1E Saat Terkopel Beban}

Dalam pengalamatan Input dan Output pada PLC seperti pada Tabel 2 yaitu $0.00-0.05$ sebagai digital input dan Tabel 3 yaitu 100.00-100.05 sebagai digital output. Pengalamatan input dan output dari rangkaian kontrol motor induksi tiga phasa pada saat terkopel beban pada Tabel 2 dan Tabel 3.

Tabel 2. Daftar input PLC Terkopel Beban

\begin{tabular}{cc}
\hline Pengalamatan & Keterangan \\
\hline 0.00 & Motor Stop \\
0.01 & Motor Forward \\
0.02 & Motor Reverse \\
0.03 & Lampu (100 W) \\
0.04 & Lampu (200 W) \\
0.05 & Lampu (300 W) \\
\hline
\end{tabular}

Tabel 3. Daftar output PLC Terkopel Beban

\begin{tabular}{cc}
\hline Pengalamatan & Keterangan \\
\hline 100.00 & R 1 \\
100.01 & R 2 \\
100.02 & R 3 \\
100.03 & R 4 \\
100.04 & R 5 \\
100.05 & R 6 \\
100.06 & R7
\end{tabular}


100.07

$\mathrm{R} 8$

Pengalamatan Input dan Output PLC Omron CP1E Saat Terkopel Beban

Selanjutnya untuk pengalamatan Input dan Output tidak terkopel beban pada PLC seperti pada Tabel 4 yaitu 0.00-0.03 sebagai digital input dan selanjutnya Tabel 5 yaitu 100.00-100.07 sebagai digital output.

Tabel 4. Daftar input PLC tidak Terkopel Beban

\begin{tabular}{cc}
\hline Pengalamatan & Keterangan \\
\hline 0.00 & Selector OFF \\
0.01 & Selector ON 1 \\
0.02 & Selector ON 2 \\
\hline
\end{tabular}

Tabel 5. Daftar output PLC tidak Terkopel Beban

\begin{tabular}{cc}
\hline Pengalamatan & Keterangan \\
\hline 100.00 & R 1 \\
100.01 & R 2 \\
100.02 & R 3 \\
100.03 & R 4 \\
100.04 & R 5 \\
100.05 & R 6 \\
100.06 & R 7 \\
100.07 & R 8 \\
\hline
\end{tabular}

\section{Membuat Program PLC}

Untuk memprogram PLC bahasa program yang digunakan adalah ladder diagram dengan menggunakan software CX-Programmer. Sebelum membuka lembar kerja $C X$-Programmer terlebih dahulu melakukan konfigurasi tipe PLC yang akan digunakan seperti pada Gambar 6.

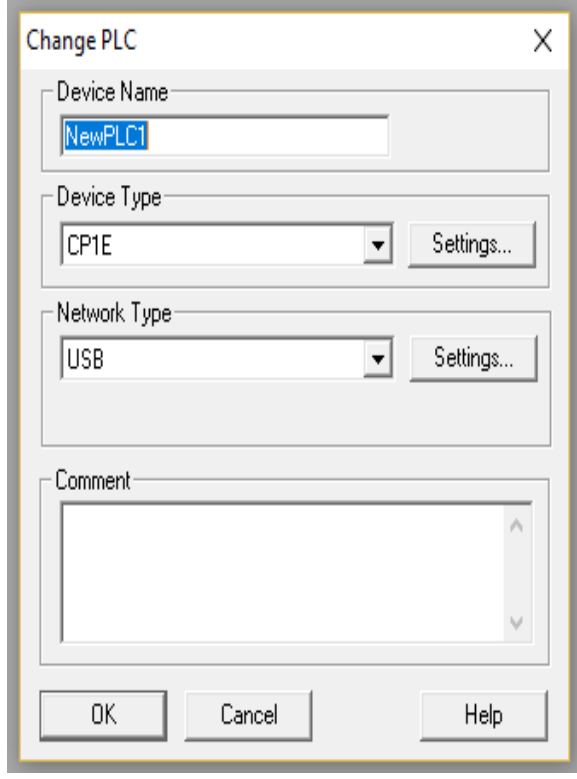

Gambar 6. Konfigurasi PLC Omron CPIE

Kemudian selanjutnya setting CPU, karena ini merupakan bagian utama dari $P L C$ sebagai $C P U$ terhadap sinyal dari data input seperti Gambar 7.

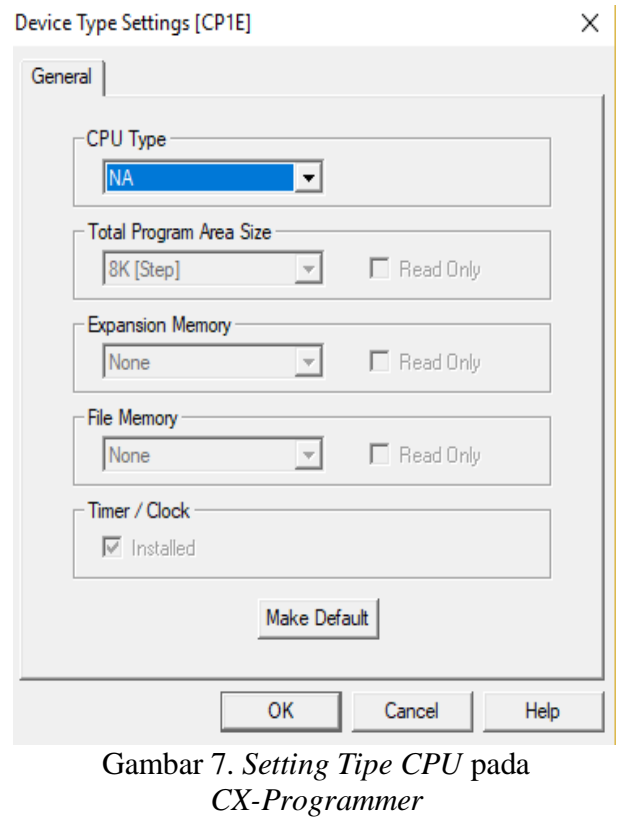

Ladder Diagram (LD) Pengontrolan VSD Terkopel Beban

Untuk rancangan Ladder Diagram (LD) untuk pengontrolan VSD pada saat terkopel beban seperti pada Gambar 8 : 


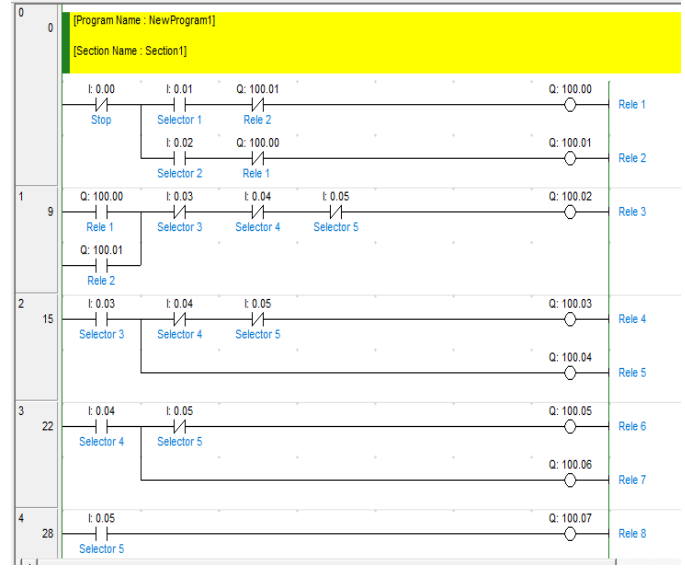

Gambar 8. Ladder Diagram (LD) Pengontrolan VSD Terkopel Beban

Ladder Diagram (LD) Pengontrolan VSD Tidak Terkopel Beban

Rancangan Ladder Diagram (LD) untuk pengontrolan VSD pada saat tidak terkopel beban seperti pada Gambar 9 :

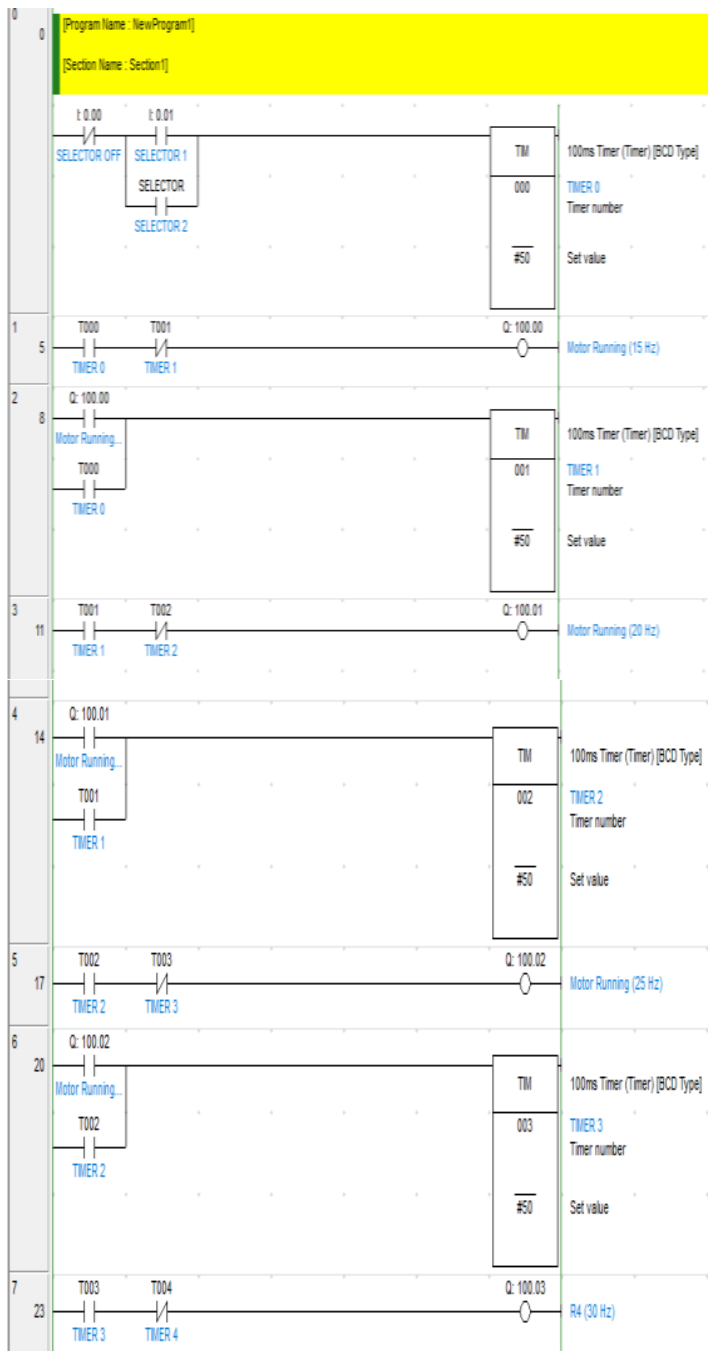

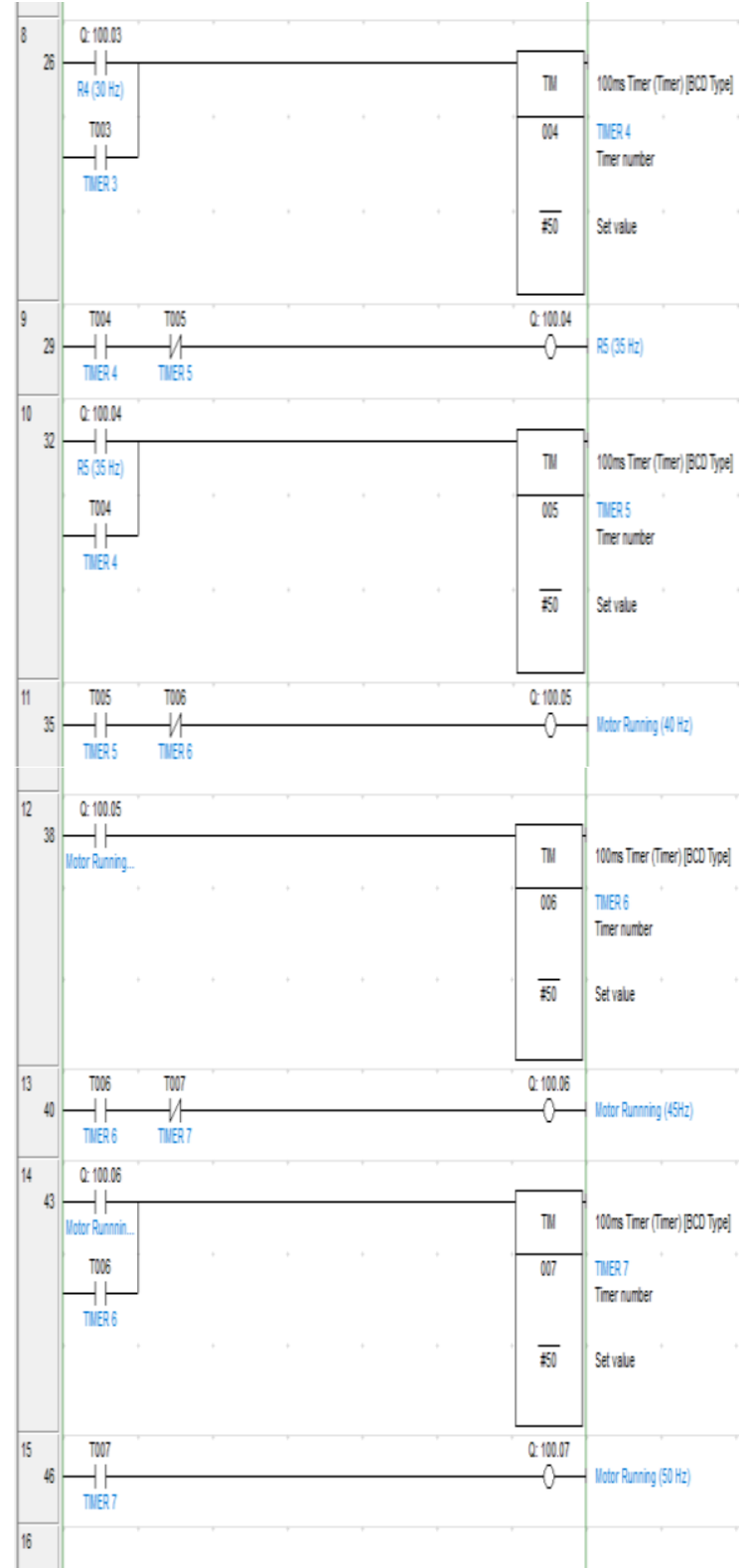

Gambar 9. Ladder Diagram (LD) Pengontrolan VSD Tidak Terkopel Beban

\section{Motor Induksi}

Motor induksi merupakan motor arus bolak balik (AC) yang paling luas digunakan. Penamaannya berasal dari kenyataan bahwa arus rotor motor ini diperoleh bukan dari sumber tertentu, tetapi merupakan arus yang terinduksi sebagai akibat adanya relatif antara putaran rotor dengan medan putar (Rotating Magnetic Field) yang dihasilkan oleh arus stator [3].

Belitan stator yang dihubungkan dengan suatu sumber tegangan tiga phasa akan menghasilkan medan magnet yang berputar dengan kecepatan sinkron. Medan putar pada stator tersebut akan memotong konduktor-konduktor pada rotor sehingga 
terinduksi arus dan rotor akan turut berputar mengikuti medan putar stator. Perbedaan putaran relatif antara stator dan rotor disebut slip. Salah satu kelemahan motor induksi adalah sulit diatur kecepatannya [3].

Bila dilihat dari jumlah phasa tegangan yang digunakan maka motor induksi dapat dibedakan menjadi 2 jenis yaitu [3].

a. Motor Induksi Satu Phasa

Disebut motor satu phasa karena untuk menghasilkan tenaga mekanik, pada motor tersebut disuplai dengan tegangan satu phasa. Didalam praktiknya, yang sering digunakan adalah motor satu phasa dengan lilitan dua phasa. Dikatakan demikian, karena di dalam motor satu phasa lilitan statornya terdiri dari dua jenis lilitan, lilitan pokok dan lilitan bantu. Macammacam motor induksi satu phasa yaitu motor kapasitor, shaded mole motor (Motor Bayangan Kutub), dan motor Split Phasa.

b. Motor Induksi tiga phasa

Disebut motor induksi tiga phasa karena untuk menghasilkan tenaga mekanik, pada motor tersebut disuplai dengan sumber tegangan tiga phasa. Jenis-jenis motor ditinjau dari jenis rotor yang digunakan, yaitu motor dengan rotor lilit dan motor dengan rotor sangkar tupai.

\section{Prinsip Kerja Motor Induksi Tiga Phasa}

Ketika catu daya AC tiga phasa terhubung ke stator terminal induksi motor, arus arus bolak-balik tiga phasa dalam gulungan stator. Arus ini mengatur dan mengubah medan magnet (pola fluks) yang berputar di sekitar bagian dalam stator. Kecepatan rotasi sinkron dengan frekuensi daya listrik dan disebut kecepatan sinkron. Kecepatan putar sinkron medan magnet dirumuskan dengan [4].

$$
n_{s}=\frac{120 \times f}{p}
$$

Atau untuk mencari kecepatan sudut [4] ;

$$
\omega_{s}=\frac{2 \times \pi \times n_{s}}{60}
$$

Keterangan :

$n_{s}=$ Kecepatan medan putar stator (rpm)

$\omega_{\mathrm{s}}=$ Kecepatan sudut stator $(\mathrm{rad} / \mathrm{s})$

$p=$ Jumlah kutub

$f=$ Frekuensi tegangan masukan $(\mathrm{Hz})$

Fluksi yang berputar tersebut akan memotong batang konduktor pada rotor. Akibatnya pada kumparan rotor timbul tegangan induksi gaya gerak listrik sebesar $E_{2}$ yang besarnya dapat dihitung dengan persamaan berikut [5].

$$
E_{2}=4,44 \times f_{2} \times \mathrm{N}_{2} \times \phi_{\mathrm{m}}
$$

Keterangan :

$E_{2}=$ Tegangan induksi pada saat rotor dalam keadaan diam (Volt)

$f_{2}=$ Frekuensi rotor $(\mathrm{Hz})$

$N_{2}=$ Jumlah lilitan kumparan rotor

$\Phi_{m}=$ Fluksi maksimum $(\mathrm{Wb})$

Slip

Perbedaan kecepatan antara medan putar stator dengan rotor tergantung pada besarnya beban dari motor tersebut. Perbedaan putaran ini disebut dengan slip (s) yang dinyatakan dalam (\%). Harga slip selalu berubah-ubah tergantung dari besarnya beban yang dipikul yaitu dari $100 \%$ saat start sampai dengan $0 \%$ saat diam $\left(\mathrm{n}_{\mathrm{s}}=\mathrm{n}_{\mathrm{r}}\right)$. Perbedaan putaran antara putaran medan stator dan putaran rotor dapat dihitung dengan persamaan berikut [3].

$$
s=\frac{n_{s}-n_{r}}{n_{s}} \times 100 \%
$$

Dengan menggunakan rasio slip, kita juga dapat menentukan kecepatan rotor [5].

$$
n_{r}=(1-s) \times n_{s}
$$

Atau ;

$$
\omega_{r}=(1-s) \times \omega_{s}
$$

Keterangan :

$n_{s} \quad=$ Kecepatan medan putar stator $(\mathrm{rpm})$

$n_{r}=$ Kecepatan putar rotor $(\mathrm{rpm})$

$\omega_{r}=$ Kecepatan sudut rotor $(\mathrm{rad} / \mathrm{s})$

$s \quad=\operatorname{Slip}(\%)$

\section{Hubungan Tegangan Dengan Frekuensi}

Untuk pemakaian VSD terhadap pengaturan motor induksi tiga phasa harus memperhatikan hal berikut [6].

1. Jika frekuensi kita naikkan dari $50 \mathrm{~Hz} \mathrm{~s} / \mathrm{d} 100 \mathrm{~Hz}$ dengan tegangan suplai konstan maka load current akan turun sebesar $50 \%$ dan torque akan drop sebesar $100 \%$.

2. Jika frekuensi kita turun dari $50 \mathrm{~Hz}$ s/d $25 \mathrm{~Hz}$ dengan tegangan suplai konstan maka load current akan naik menjadi dua kali dan motor akan over heat.

Jadi kesimpulannya bahwa perubahan frekuensi adalah berbanding terbalik terhadap perubahan arus. Rasio perubahan frekuensi terhadap tegangan tersebut dihitung dengan rumus [6].

$$
\frac{V_{1}}{f_{1}}=\frac{V_{n}}{f_{1}}
$$


Atau ;

$$
\mathrm{V}_{\mathrm{n}}=\frac{V_{1}}{f_{1}} \times f_{n}
$$

Keterangan :

$\mathrm{V}_{1}=$ Tegangan Aktual (Volt)

$\mathrm{V}_{\mathrm{n}}=$ Tegangan Baru (Volt)

$\mathrm{f}_{\mathrm{n}}=$ Frekuensi Baru $(\mathrm{Hz})$

\section{HASIL DAN PEMBAHASAN}

Perhitungan kecepatan motor induksi pada saat tidak terkopel beban dengan frekuensi $50 \mathrm{~Hz}$.

Kecepatan motor induksi menggunakan persamaan (1) dan kecepatan rotor menggunakan persamaan (5).

$$
\begin{aligned}
n_{s} & =\frac{120 \times f}{p} \\
& =\frac{120 \times 50}{20} \\
& =3000 \mathrm{rpm} \\
n_{r} & =(1-\mathrm{s}) \times n_{s} \\
& =(1-0,066) \times 3000 \\
& =2802 \mathrm{rpm}
\end{aligned}
$$

Untuk slip motor induksi menggunakan persamaan (4).

Adapun hasil perhitungan motor induksi tiga phasa saat terkopel beban diperlihatkan pada tabel 6 .

Tabel 6. Hasil Perhitungan Motor Induksi Tiga Phasa

\begin{tabular}{ccccc}
\hline $\begin{array}{c}\text { Frekuensi } \\
(\mathrm{Hz})\end{array}$ & $\begin{array}{c}\text { Tegangan } \\
(\text { Volt })\end{array}$ & $\begin{array}{c}\text { Torka } \\
(\mathrm{N} . \mathrm{m})\end{array}$ & $\begin{array}{c}\text { Daya } \\
\text { (Watt) }\end{array}$ & $\begin{array}{c}\text { Kecepatan } \\
(\mathrm{rpm})\end{array}$ \\
\hline 15 & 66 & 1,594 & 140,287 & 840,6 \\
20 & 88 & 1,583 & 185,709 & 1120 \\
25 & 110 & 1,591 & 233,355 & 1401 \\
30 & 132 & 1,595 & 280,758 & 1681 \\
35 & 154 & 1,591 & 326,681 & 1961 \\
40 & 176 & 1,591 & 372,358 & 2241 \\
45 & 198 & 1,587 & 418,930 & 2521 \\
50 & 220 & 1,595 & 467,917 & 2802 \\
\hline
\end{tabular}

Riski, Studi Pengaturan Kecepatan Motor Induksi Tiga Phasa Menggunakan Variable Speed Drive (Vsd) Berbasis Programmable Logic Controller (Plc) 
Dari Tabel 6 dapat dibuatkan beberapa grafik yang ditunjukkan pada Gambar 10 frekuensi terhadap tegangan, Gambar 11 frekuensi terhadap kecepatan dan Gambar 12 Frekuensi Terhadap Torka Motor Induksi.

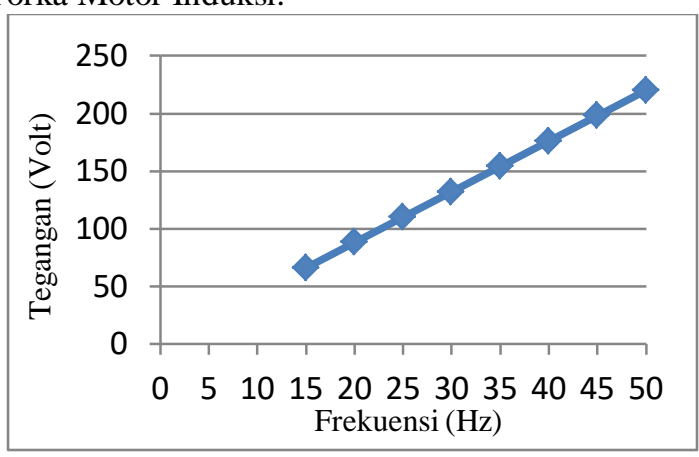

Gambar 10. Frekuensi Terhadap Tegangan Motor Induksi

Gambar 10 menunjukkan hubungan antara frekuensi terhadap tegangan motor induksi tiga phasa. Perubahan frekuensi akan meningkatkan atau menurunkan tegangan yang dihasilkan.

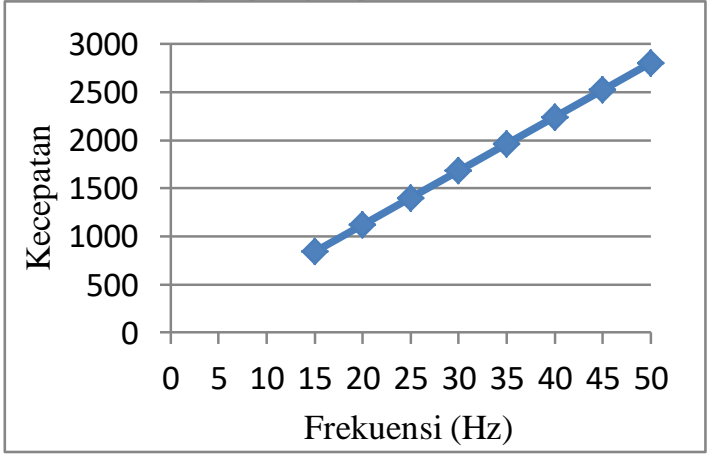

Gambar 11. Frekuensi Terhadap Kecepatan Motor Induksi

Pada Gambar 11 terdapat grafik hubungan antara frekuensi terhadap kecepatan pada motor induksi tiga phasa. Frekuensi yang diatur mulai dari $15 \mathrm{~Hz}$ sampai $50 \mathrm{~Hz}$, frekuensi berbanding lurus dengan kecepatan motor induksi tiga phasa, semakin besar frekuensi yang diatur maka akan semakin cepat putaran pada motor induksi tiga phasa yang dihasilkan.

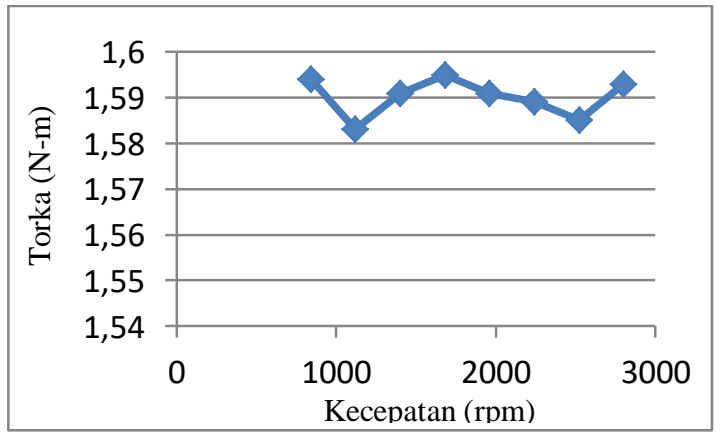

Gambar 12. Kecepatan Terhadap Torka Motor Induksi

Gambar 12 menunjukkan grafik hubungan kecepatan terhadap torka motor induksi tiga phasa pada saat motor induksi tiga phasa tidak terkopel beban, torka yang dihasilkan 1,58 N.m sampai 1,60 N.m.

\section{KESIMPULAN}

Dari analisa yang didapat setelah melakukan penelitian, maka dapat diambil kesimpulan sebagai berikut :

1. Kecepatan motor induksi tiga phasa saat tidak terkopel beban sebesar $2802 \mathrm{rpm}$ dengan frekuensi $50 \mathrm{~Hz}$, kecepatan $1681 \mathrm{rpm}$ pada frekuensi $30 \mathrm{~Hz}$ dan kecepatan 840,6 rpm pada frekuensi $15 \mathrm{~Hz}$.

2. Kecepatan motor induksi tiga phasa saat terkopel beban sebesar $1434 \mathrm{rpm}$ dengan frekuensi 25,6 Hz, kecepatan $1462 \mathrm{rpm}$ pada frekuensi 26,1 Hz dan kecepatan $1496 \mathrm{rpm}$ pada frekuensi $26,6 \mathrm{~Hz}$.

3. Torka motor induksi tiga phasa saat tidak terkopel beban sebesar 1,591 N.m dengan kecepatan $1401 \mathrm{rpm}$, saat terkopel beban sebesar 2,089 N.m dengan kecepatan 1434 rpm.

\section{DAFTAR PUSTAKA}

[1] Atmam, Zulfahri , A. Tanjung (2018), Analisa Penggunaan Energi Listrik Motor Induksi Tiga Phasa Menggunakan Variable Speed Drive (VSD), ISSN : 2548-6888, pp : 52-59.

[2] Putra, E. A., (2017), Konsep Pemograman dan Aplikasi, Gava Media, Yogyakarta.

[3] Zuhal, (1988), Zuhal Teknik Tenaga Listrik. PT. Gramedia Pustaka Utama, Jakarta

[4] Barnes, M., (2003), Variable Speed Drives and Power Electronics, Australia.

[5] Chapman Stephen J., (2004), Electric Machinery Fundamental, McGraw-Hill, New York.

[6] Isdiyarto, (2010), Dampak Perubahan Putaran Terhadap Unjuk Kerja Motor Induksi 3 Phasa Jenis Rotor Sangkar, Teknik Elektro UNS, Vol 1, No. 2. 